\title{
A Study of Clinostomum (Trematode) and Contracaecum (Nematode) Parasites Affecting Oreochromis Niloticus in Small Abaya Lake, Silite Zone, Ethiopia
}

\author{
Mohammed Reshid", Marshet Adugna ${ }^{2}$, Yisehak Tsegaye Redda ${ }^{*}$, Nesibu Awol ${ }^{1}$ and Awot Teklu ${ }^{1}$ \\ ${ }^{1}$ Mekelle University College of Veterinary Medicine, P.O.Box 231 Mekelle, Ethiopia \\ ${ }^{2}$ Ethiopian Institute of Agricultural Research, National Fisheries and other Aquatic Life Research Center, P.O. Box 64, Sebeta, Ethiopia
}

\begin{abstract}
This study was conducted at Lake Small Abaya Ethiopia, to identify Clinostomum and Contracaecum parasites from a total of 384 O. niloticus species sampled during November 2013- April 2014. Of the 384 samples collected, $138(35.9 \%)$ were infested with nematode of Contracaecum species and $72(18.8 \%)$ were infected with trematode of Clinostomum species. The intensity of infestation by Contracaecum and Clinostomum was 1-19 worms per fish (mean intensity=4.47) and 1-12 worms per fish (mean intensity=3.56) respectively. There was no significant difference $(p>0.05)$ in the prevalence of infestation among host sex, host size and host weight. There was no any statistically significant $(p>0.05$ ) correlation between the number of Clinostomum, Contracaecum and the mixed number of parasites and the fish's condition. In conclusion, the study show that fish parasite are prevalent in Small Abaya lake. Hence, further studies and appropriate control measure are recommended to reduce their effect on the fishery industry and public health.
\end{abstract}

Keywords: Clinostomum; Contracaecum; Condition factor; O. niloticus; Small abaya lake

\section{Introduction}

Ethiopia has large water resources, with an estimated surface area of $733 \mathrm{k} \mathrm{km}^{2}$ of major lakes and reservoirs, $275 \mathrm{~km}^{2}$ of small water bodies and $7285 \mathrm{~km}$ long rivers within the country [1]. As a result of these ecological variations, Ethiopia has been the home of highly diversified flora and fauna. More than 200 species of fish are known to occur in lakes, rivers and reservoirs in Ethiopia [2]. The country depends on its inland water bodies for fish supply to its population.

Mostly, Nile tilapia (Oreochromis niloticus) has been introduced throughout the country because of its adaptive abilities and its suitability to match Ethiopian consumers' preferences. As a consequence of its natural occurrence plus its introduction into different water bodies, it is contributing about $40.9 \%$ of the 13,253 tons of commercial fish catch in $2007 / 2008$ [3].

One of the problems of the fishery sector in the wild populations are parasites and disease conditions of fish. Parasitic diseases reduce fish production by affecting the normal physiology and if left uncontrolled, it can result in mass mortalities or in some cases, can be served as a source of infection for human and other vertebrates that consumed fish [4]. Presence of a massive number of parasites on each fish might constitute a real threat to the fish population and require immediate action [5].

The digenea parasites are the main endo-parasites of fishes; the greater majority of fish are susceptible to infection with different stages of these parasites [6]. Clinostomum species, digenetic termatode, are common fish parasites throughout the world and the final hosts of this fluke are generally piscivorous birds, including herons and egrets [7]. The metacercariae embedded in the tissues of fish are freed in the host stomach and migrates up to the esophagus, and then attach to the throat or mouth cavity. Human infections are known to be resulting from eating raw freshwater fish. Metacercarial infection in fish is the main source of disease with subsequent economic loss. Metacercariae may affect growth and survival, or disfigure fish so that they loss their market value as a food or ornamental product [8].
Most adult nematodes are found in the intestine of fish but their larval stage, which is infective to human, has the greatest impact on the consumer acceptance of fish as a source of protein [9]. Contracaecum is an anisasakid nematode that infects fish-eating bird and marine mammals. Larval stage of Contracaecum usually occurs in the body cavity and mesenteries of fish while the adults occur in the gut of piscivorous birds, notably pelicans, cormorant's herons and darters [10].

So far, very few diseases have been described from fish of Ethiopia waters. Moreover there is no report of disease and prevalence of parasitic infection in fish in small Abaya Lake.

Therefore the objectives of the current study were: to determine the prevalence of Clinostomum and Contracaecum species in Oreochromis niloticus in Small Abaya Lake.

\section{Materials and Study Methodology}

\section{The study area}

The study was conducted at Lake Small Abaya $\left(7^{\circ} 2903^{\prime} 65^{\prime} \mathrm{N}\right.$ latitude and $38^{\circ} 03^{\prime} 17.79^{\prime \prime}$ E longitude), which is located at altitude of 1835 meter above the sea level. The Lake covers a total area of $1253 \mathrm{ha}$ and it is shallow lake with the maximum depth of $9 \mathrm{~m}$. The mean monthly minimum and maximum temperatures varies between $10.8^{\circ} \mathrm{C}$

*Corresponding author: Redda YT, Mekelle University College of Veterinary Medicine, P.O. Box 231 Mekelle, Ethiopia, Tel: 880-171-2141273; E-mail yistseg@yahoo.com

Received November 17, 2014; Accepted January 13, 2015; Published February 15, 2015

Citation: Reshid M, Adugna M, Redda YT, Awol N, Teklu A (2015) A Study of Clinostomum (Trematode) and Contracaecum (Nematode) Parasites Affecting Oreochromis Niloticus in Small Abaya Lake, Silite Zone, Ethiopia. J Aquac Res Development 6: 316. doi:10.4172/2155-9546.1000316

Copyright: $\odot 2015$ Reshid M, et al. This is an open-access article distributed under the terms of the Creative Commons Attribution License, which permits unrestricted use, distribution, and reproduction in any medium, provided the original author and source are credited. 
Citation: Reshid M, Adugna M, Redda YT, Awol N, Teklu A (2015) A Study of Clinostomum (Trematode) and Contracaecum (Nematode) Parasites Affecting Oreochromis Niloticus in Small Abaya Lake, Silite Zone, Ethiopia. J Aquac Res Development 6: 316. doi:10.4172/21559546.1000316

Page 2 of 4

to $14.1^{\circ} \mathrm{C}$ and $22.5^{\circ} \mathrm{C}$ to $28.7^{\circ} \mathrm{C}$, respectively throughout sampling period. Before stocking, there were no commercially important fish species in the lake except for the naturally occurring Barbus species. In the 2005 National Fisheries and other Aquatic Life Research Center stocked Oreochromis niloticus or Nile tilapia and Tilapia zilli fry in to Lake small Abaya.

\section{Study design}

A cross sectional study was conducted from November 2013 to April 2014 at Small Abaya Lake to determine the prevalence of parasitic infestation of O. niloticus /Nile tilapia/. The desired sample size was calculated using the formula given by Thrusfield [11]. By considering 95\% confidence interval, 5\% desired absolute precision and 50\% expected prevalence and the total number of sample found to be 384 .

\section{Study methodology}

Sample collection: A total of 384 O. niloticus species of fish were sampled and examined. All the fish were caught using gill net with mesh size ranging from 6 to $12 \mathrm{~cm}$. Harvested fishes were transported in ice to Ethiopian Institute of Agricultural Research, National Fisheries and other Aquatic Life Research Center, Sebeta, for analysis. The length (L) of fish was taken from the tip of the snout to the posterior tip of the caudal fin and was measured to the nearest $\pm 0.1 \mathrm{~cm}$. The weight of the fish was measured to the nearest gram using an electric balance.

Laboratory examinations: Each fish was opened and its internal organs were fully examined for parasites. The entire digestive system was removed and placed in a Petri-dish with physiological saline, and the gut was divided into sections. The muscles, gonads, liver, and heart were examined with the aid of a dissection microscope and a phase contrast light microscope at 10 and 40 magnifications. Parasites were counted, their location recorded, and preserved in $70 \%$ ethanol. Identification of most parasites was made immediately following standard keys in literature [12-14].

\section{Data analysis}

The data obtained from the laboratory finding were summarized and then analyzed using SPSS version 16 analyzing software. Chisquare was applied to test association between sex, weight, and standard length with occurrence of the disease. The effect of the parasites on the health of their host was determined by calculating Fulton's condition factor $(K)$, a measure of an individual fish's health that uses standard weight. Proposed by Fulton in 1904, it assumes that the standard weight of a fish is proportional to the cube of its length.

$$
K=100(W / L 3)
$$

Where $W$ is the whole body wet weight in grams and $L$ is the length in centimeters; the factor 100 is used to bring $\mathrm{K}$ close to a value of one. Pearson correlation was done to find the correlation between the body conditions of fish with the number of parasites.

Mean intensity was also calculated using the formula given below

$$
\text { Mean Intensity }=\frac{\text { Total number of parasites in a given host }}{\text { Total number of hosts inf ected }}
$$

\section{Results}

\section{Monthly variations}

Protein content significantly varied from $6.05 \pm 0.45 \%$ with $\mathrm{T}_{6}$ (banana leaf) at $6^{\text {th }}$ month (September, 2010) to $31.20 \pm 0.32 \%$ with treatment $\mathrm{T}_{3}$ (mustard oilcake) at $2^{\text {nd }}$ month (May, 2010). Lipid content significantly varied from $2.95 \pm 0.21 \%$ with treatment $\mathrm{T}_{6}$ (banana leaf) at $5^{\text {th }}$ month (August, 2010) to $13.72 \pm 0.36 \%$ with treatment $\mathrm{T}_{3}$ (mustard oilcake) at $4^{\text {th }}$ month (July, 2010). Carbohydrate significantly varied from $32.85 \pm 0.14 \%$ with treatment $\mathrm{T}_{3}$ (mustard oilcake) at $4^{\text {th }}$ month (July, 2010) to $66.35 \pm 0.32 \%$ with $\mathrm{T}_{2}$ (wheat bran) at $3^{\text {rd }}$ month (June, 2010). In the same feed item no significant difference in the nutrient content was found during the study period (Tables 1-4).

\section{Mean variations}

The variations in the mean values of nutrient contents (protein, lipid and carbohydrate) with different treatments of feed items are presented in Table 3 and Figures 1-3. Protein content significantly varied from $6.18 \pm 0.13 \%$ with treatment $\mathrm{T}_{6}$ (banana leaf) to $30.53 \pm$ $0.40 \%$ with treatment $\mathrm{T}_{3}$ (mustard oilcake). Lipid content significantly varied from $3.06 \pm 0.09 \%$ with treatment $\mathrm{T}_{6}$ (banana leaf) to $13.33 \pm$ $0.10 \%$ with treatment $\mathrm{T}_{3}$ (mustard oilcake). Carbohydrate significantly varied from $32.95 \pm 0.29 \%$ with treatment $\mathrm{T}_{3}$ (mustard oilcake) to 66.12 $\pm 0.47 \%$ with treatment $\mathrm{T}_{2}$ (wheat bran).

\section{Discussion}

\section{Monthly variations of the nutrient contents}

Protein content varied from $6.05 \pm 0.45 \%$ with $\left(\mathrm{T}_{6}\right.$ at $6^{\text {th }}$ month) to $31.20 \pm 0.32 \%$ ( $\mathrm{T}_{3}$ at $2^{\text {nd }}$ month). Lipid content ranged from $2.95 \pm$ $0.21 \%\left(\mathrm{~T}_{6}\right.$ at $5^{\text {th }}$ month $)$ to $13.72 \pm 0.36 \%\left(\mathrm{~T}_{3}\right.$ at $4^{\text {th }}$ month $)$. Carbohydrate

\begin{tabular}{|l|c|c|c|c|}
\hline $\begin{array}{l}\text { Parasites } \\
\text { Taxonomy }\end{array}$ & $\begin{array}{c}\text { No. of } \\
\text { infected }\end{array}$ & $\begin{array}{c}\text { Prevalence } \\
\%\end{array}$ & $\begin{array}{c}\text { Total No. } \\
\text { of parasites } \\
\text { recovered }\end{array}$ & $\begin{array}{c}\text { Mean } \\
\text { intensity }\end{array}$ \\
\hline Contracaecum & 138 & $35.9 \%$ & 617 & 4.47 \\
\hline Clinostomum & $\mathbf{7 2}$ & $18.8 \%$ & 257 & 3.56 \\
\hline Total & $\mathbf{2 1 0}$ & $\mathbf{5 4 . 7 \%}$ & $\mathbf{8 7 4}$ & $\mathbf{4 . 0}$ \\
\hline
\end{tabular}

Table 1: The prevalence and mean intensity of Contracaecum and Clinostomum.

\begin{tabular}{|l|c|c|c|}
\hline Sex & \multicolumn{3}{|c|}{ Parasite genera } \\
\hline Female $(\mathrm{n}=144)$ & Clinostomum & Contracaecum & $\%$ \\
\hline Male $(\mathrm{n}=\mathbf{2 4 0 )}$ & $23(\mathbf{1 6 \% )}$ & $56(38.9 \%)$ & $54.9 \%$ \\
\hline Total $(\mathbf{n = 3 8 4 )}$ & $\mathbf{7 2 ( 1 8 . 8 \% )}$ & $82(34.2 \%)$ & $54.6 \%$ \\
\hline
\end{tabular}

$\chi^{2}=0.03 ; \mathrm{P}>0.05 ; \mathrm{df}=1$

Table 2: The prevalence of parasites in relation to host sex.

\begin{tabular}{|l|c|c|c|}
\hline \multicolumn{4}{|c|}{ Parasite genera } \\
\hline Length (n) & Clinostomum & Contracaecum & Prevalence \% \\
\hline $11-17(64)$ & $8(12.5 \%)$ & $26(40.6 \%)$ & $8.85 \%$ \\
\hline $17.5-23(242)$ & $47(19.4 \%)$ & $86(35.5 \%)$ & $34.63 \%$ \\
\hline $23.5-29.5(78)$ & $17(21.8 \%)$ & $26(33.3 \%)$ & $11.19 \%$ \\
\hline Total (384) & $\mathbf{7 2 ( 1 8 . 8 \% )}$ & $\mathbf{1 3 8}(\mathbf{3 5 . 9} \%)$ & $\mathbf{5 4 . 7 \%}$ \\
\hline
\end{tabular}

$\chi^{2=0.076 ; p>0.05 ; d f=2}$

Table 3: Prevalence of parasites that infect fish in relation to the standard length of the host $(\mathrm{cm})$

\begin{tabular}{|l|c|c|c|}
\hline \multicolumn{4}{|c|}{ Parasite genera } \\
\hline Weight $(\mathbf{n})$ & Clinostomum & Contracaecum & Prevalence\% \\
\hline $26-135(n=125)$ & $19(11.2 \%)$ & $54(43.2 \%)$ & $19.0 \%$ \\
\hline $136-178(n=148)$ & $28(18.9 \%)$ & $51(34.5 \%)$ & $20.5 \%$ \\
\hline $179-549(n=111)$ & $25(22.5 \%)$ & $33(29.7 \%)$ & $15.1 \%$ \\
\hline Total $(\mathbf{n}=\mathbf{3 8 4})$ & $\mathbf{7 2 ( 1 8 . 8 \% )}$ & $\mathbf{1 3 8 ( 3 5 . 9 \% )}$ & $\mathbf{5 4 . 7 \%}$ \\
\hline
\end{tabular}

$\chi^{2}=1.063 ; P>0.05 ; d f=2$

Table 4: The Prevalence of parasite infections in fish of various host weight range. 
Citation: Reshid M, Adugna M, Redda YT, Awol N, Teklu A (2015) A Study of Clinostomum (Trematode) and Contracaecum (Nematode) Parasites Affecting Oreochromis Niloticus in Small Abaya Lake, Silite Zone, Ethiopia. J Aquac Res Development 6: 316. doi:10.4172/21559546.1000316

Page 3 of 4

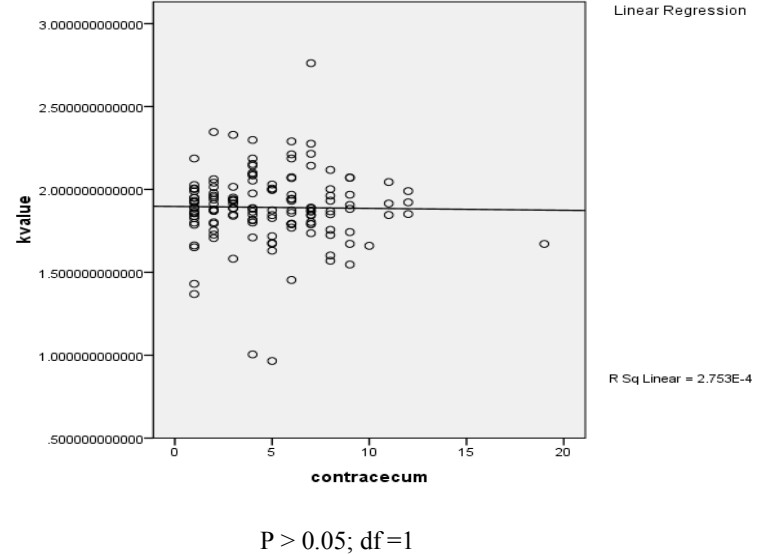

Figure 1: Relationship between condition factor and the number of Contracaecum parasites.

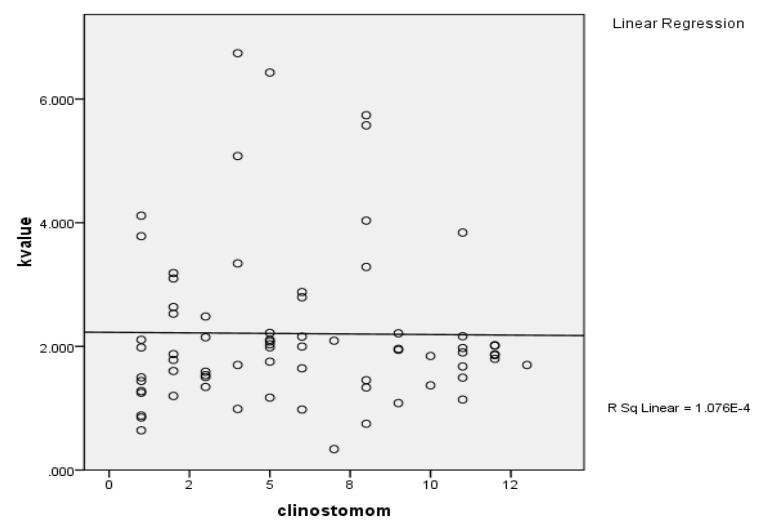

$P>0.05 ; \mathrm{df}=1$

Figure 2: Relationship between condition factor and the number of Clinostomum parasites.

content ranged from $32.85 \pm 0.14 \%\left(\mathrm{~T}_{3}\right.$ at $4^{\text {th }}$ month) to $66.35 \pm 0.32 \%$ ( $\mathrm{T}_{2}$ at $3^{\text {rd }}$ month). Suresh and Mandal worked on the determination of nutritive value of rice bran, mustard oil cake and Azolla for a period of 4 months from July to October. In rice bran they found crude protein and crude fibre as $12.6 \%$ and $21.9 \%$, respectively. In mustard oilcake, crude protein and crude fibre was $38.6 \%$ and $6.8 \%$, respectively and in Azolla, crude protein and crude fibred was $26.5 \%$ and $20.4 \%$, respectively. Sithara and Kamalaveni worked on the formulation of low cost fish feed using Azolla as a protein supplement during September to March and reported 20-25.5\% protein in Azolla. Ebrahim used Azolla as tilapia diet for a period of 90 days in summer season and reported $20 \%$ protein in Azolla. Fasakin and Balogan worked on the nutritional aspects of Azolla in August, 1997 and reported 20.9\% protein in Azolla.

Present findings also indicated that in case of same feed item, no significant difference was found in the nutrient content at different months (Tables 1-4). This might be due to no major change in the temperature was found to affect the growth and composition of Azolla during the study period. This statement was almost agreed with Lumpkin and Plucknett who reported that change in Azolla composition was subjected to change in environment. Statement also agreed with Van-Hove and Ebrahim who reported that change in
Azolla composition was subjected to change in species.

\section{Mean variation of the nutrient contents}

In the present study the protein content varied from $6.18 \pm 0.13 \%$ ( $\mathrm{T}_{6}$, banana leaf) to $30.53 \pm 0.40 \%$ ( $\mathrm{T}_{3}$, mustard oilcake), lipid content varied from $3.06 \pm 0.09 \%\left(\mathrm{~T}_{6}\right.$, banana leaf) to $13.33 \pm 0.10 \%\left(\mathrm{~T}_{3}\right.$, mustard oilcake) and carbohydrate content varied from $32.95 \pm 0.29 \%$ ( $\mathrm{T}_{3}$, mustard oilcake) to $66.12 \pm 0.47 \%$ ( $\mathrm{T}_{2}$, wheat bran). The highest protein and lipid content was found in treatment $\mathrm{T}_{3}$ (mustard oilcake) whereas the highest carbohydrate content was found in treatment $\mathrm{T}_{2}$, wheat bran $(66.12 \pm 0.47 \%)$ followed by $\mathrm{T}_{4}$, Azolla (50.21 $\left.\pm 0.54 \%\right), \mathrm{T}_{6}$, banana leaf $(48.50 \pm 0.51 \%), \mathrm{T}_{5}$, grass $(46.36 \pm 0.16 \%), \mathrm{T}_{1}$, rice bran $(44.09 \pm 0.67 \%), \mathrm{T}_{3}$, mustard oilcake $(32.95 \pm 0.29 \%)$. Hepher reported the protein content of ricebran, wheat bran, oil cake and Azolla as $11.88 \%, 14.57 \%, 30-33 \%$ and $19.27 \%$, respectively. Banerjee and Matai determined the nutritive status of Azolla pinnata and reported protein as $21.9 \%$ and Lipid as $3.8 \%$. Gavina reported crude protein of $20.98 \%$, crude fat of $5.17 \%$ and crude fiber of $19.30 \%$ in Azolla. Tavares observed $38.8 \%$ crude protein, $3.8 \%$ crude fat and $13.2 \%$ crude fiber in dried duck weed. They also reported that the protein content of duckweeds growing on nutrient poor and nutrient rich water varied between $15-25 \%$ and $35-45 \%$ (Dry matter basis), respectively. In case of conventional feed items the major nutrient like protein varied from $14.40 \pm 0.32 \%$ (rice bran) to $30.53 \pm 0.40 \%$ (mustard oilcake). Whereas in case of non-conventional feed items the protein varied from $6.18 \pm$ $0.13 \%$ (banana leaf) to $18.58 \pm 0.09 \%$ (Azolla). Being an omnivore, the fish can also feed on vegetation and may be able to assimilate Azolla in the diets.

The chemical composition of Azolla species varies with ecotypes and with the ecological conditions and the phase of growth. The crude protein content is about 19-30 percent dry matter basis during the optimum conditions for growth. The protein contents of Azolla species are comparable to or higher than that of most other aquatic macrophytes. Aquatic weeds' are highly nutritious with protein content of $20-30 \%$, when cultivated in nutrient rich waters. Importantly, they

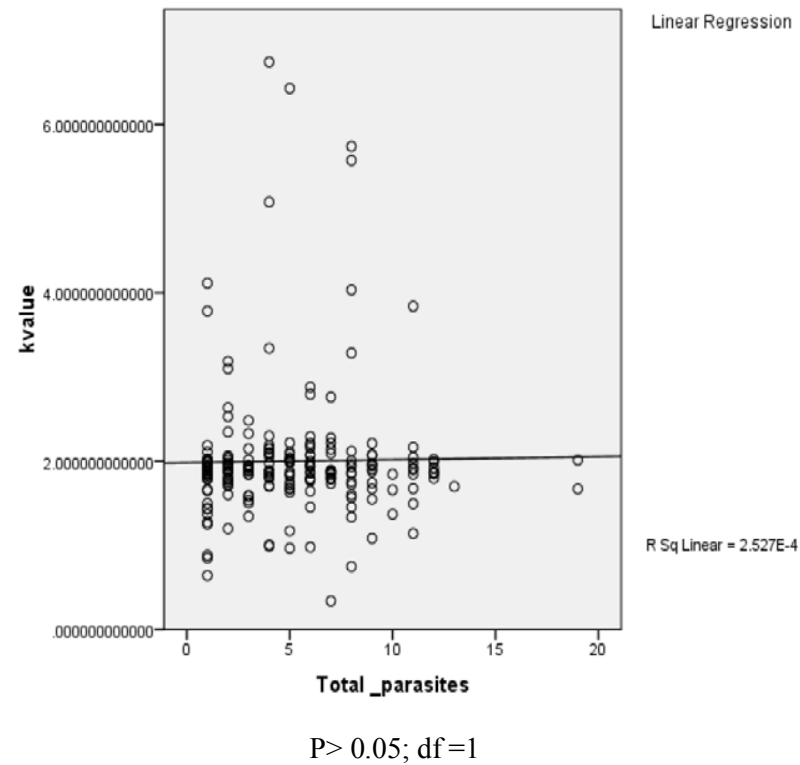

Figure 3: Relationships between condition factor and the number of mixed parasites. 
Citation: Reshid M, Adugna M, Redda YT, Awol N, Teklu A (2015) A Study of Clinostomum (Trematode) and Contracaecum (Nematode) Parasites Affecting Oreochromis Niloticus in Small Abaya Lake, Silite Zone, Ethiopia. J Aquac Res Development 6: 316. doi:10.4172/21559546.1000316

Page 4 of 4

are preferred food of a wide range of herbivorous fish such as grass carp (Ctenopharyngodon idella), silver barb (Barbonymus gonionotus, Puntius jerdoni), tilapias (Oreochromis niloticus, Tilapia rendalli, Tilapia zillii) and rohu (Labeo rohita).

Overall findings indicated that inspite of having variations in nutrient contents, monthly supply of nutrients was almost same respective feed item under non-conventional feeds as with conventional feeds. Mean values of the nutrient contents under nonconventional feed items are found potentials for the development of low cost aquaculture.

Fish feed generally constitutes $60-70 \%$ of the operational cost in intensive and semi- intensive aquaculture system. The fish feed used in aquaculture is quite expensive, irregular and short in supply in many third world countries. These feeds are sometimes adulterated, contaminated with pathogen as well as containing harmful chemicals for human health. Naturally there is a need for the development of healthy, hygienic fish feed which influences the production as well as determines the quality of cultured fish. Considering the importance of nutritionally balanced and cost-effective alternative diets for fish, almost similar expression to evaluate the nutritive value of different non-conventional feed resources, including terrestrial and aquatic macrophytes was found with Wee and Wang and Mondal and Ray. However potentials roles of aquatic and terrestrial macrophytes as supplementary feeds in fish farming were also found to be expressed with Bardach and Edwards.

\section{Conclusion}

In case of conventional feed items, protein, lipid and carbohydrate varied from $14.40 \pm 0.32 \%$ to $30.53 \pm 0.40 \%, 6.69 \pm 0.30 \%$ to $13.33 \pm$ $0.10 \%$ and $32.95 \pm 0.29 \%$ to $66.12 \pm 0.47 \%$. In case of non-conventional feed items, protein, lipid and carbohydrate varied from $6.18 \pm 0.13 \%$ to $18.58 \pm 0.09 \%, 3.06 \pm 0.09 \%$ to $6.31 \pm 0.13 \%$ and $46.36 \pm 0.16 \%$ to 50.21 $\pm 0.54 \%$. Inspite of variations weeds are moderately nutritive and low cost effective diets for fish. However, the present study did not evaluate the fish production and economy of feed and weed based systems.

\section{Recommendation}

Present findings explored the nutritive aspects of both conventional and non-conventional feed items and question raised about the response of utilizing the feed especially of aquatic weeds to fish growth and economy. Therefore, it is recommended to conduct further study on the evaluation of fish production and economy under different feed and weed based systems in polyculture ponds.

\section{Acknowledgement}

The research work was conducted under a financial support by the Ph. D. Fellowship Programme of Ministry of Science and Technology, Govt. of the People's Republic of Bangladesh which is gratefully acknowledged.

\section{References}

1. FAO (2005) Ethiopia Information on Fisheries management (From IFMC) water report No. 29, Fao, Rome, Italy.

2. JERBE (2007) Fish diversity in the main drainage system of Ethiopia.

3. MoARD (2008) Ministry of Agriculture and rural development annual report.

4. Ayotunde EO, Change ST, Okey IR (2007) Parasitological examination and food composition in the gut of feral Africa carp, LebeoCoubie in the cross river,South Estern Nigeria. Afr. Journal biotechnol 6: 625-630.

5. http://aqua.internet.com.

6. Mashengo SN (1989) Nematode Parasites of Barbus species in Lebowa and Venda, south Africa. South African J Wildlife Research 119: 35-37.

7. Aohagi Y, Shibahara T, Machida N, Yamaga Y, Kagota K, et al. (1992) Natura infections of Clinostomum complanatum (Trematoda: Clinostomatidae) in wild herons and egrets, Tottori Prefecture, Japan. J Wildl Dis 28: 470-471.

8. Paperna I (1980) Parasites, infection and disease of fish in Africa CIFA Tech.

9. Nagasawa K (1989) Note on parasites of aquatic organisms for visceral adhesion of high-seas sockeye salmon caused by the nematode Philonemaoncorhynchi. Aquabiology 11: 320-321.

10. Whitfield AK, Heeg $J$ (1977) On the life cycle of the cestode ptychobothriumbelones and nematode of the genus Contracaecum from Lake St. Lucia, Zululand. SA J sci 73: 121-122.

11. Thrusfield M (1995) Veterinary epidemiology.

12. Roberts RJ (2001) Fish Pathology.

13. Pouder DB, Curtis EW and Roy PE (2005) Common fresh water fish parasites.

14. Klinger RE, Francis-floyd R (2002) Introduction to fresh water fish parasites. 